\title{
PENGGUNAAN MODEL STUDENT TEAMS ACHIEVEMENT DIVISION (STAD) BERBANTU MEDIA GAMBAR DALAM UPAYA MENINGKATKAN KREATIVITAS DAN HASIL BELAJAR MUATAN IPA TEMA 7 "PERISTIWA DALAM KEHIDUPAN" SISWA
}

\author{
W. T. Setyowati ${ }^{1}$, N. Harjono ${ }^{2}$, G. S. Airlanda ${ }^{3}$ \\ Pendidikan Guru Sekolah Dasar, Universitas Kristen Satya Wacana, Salatiga \\ e-mail: wiwitsetyowati77@gmail.com, har.john59@gmail.com, \\ gama.airlanda@staff.uksw.edu
}

\begin{abstract}
ABSTRAK
Penelitian dilakukan untuk meningkatkan kreativitas dan hasil belajar dengan berbantuan media gambar pada muatan IPA yang ada di Tema 7 subtema 2 dan 3 . Penelitian dilaksanakan pada tanggal 7 Mei-19 Mei 2018 oleh siswa SD Negeri kecandran 01 Salatiga kelas 5 semester II tahun ajaran 2017/2018. Penelitian yang digunakan ialahpenelitian tindakan kelas. Persentase hasil pengukuran kreativitas siswa mengalami mengalami peningkatan dari prasiklus dengan presentase $40 \%$ di siklus I meningkat menjadi $80 \%$. Persentase penilaian kreativitas meningkat menjadi 90\% setelah dilakukan tindakan siklus ke II. Hasil belajar di prasiklus siswa yang dinyatakan tuntas berjumlah 13 siswa dengan persentase 43\%, dantidak tuntas 17 siswa dengan persentase 57\%. Setelah melakukan tindakan pada siklus I terjadi peningkatan ketuntasan yaitu 18 siswa tuntas dengan persentase 60\% dan 12 siswa tidak tuntas dengan persentase $40 \%$, hasil dari perbaikan siklus I belum mencapai indikator pencapaian yakni $80 \%$ ketuntasan, maka di laksanakan perbaikan siklus II. Setelah pelaksanaan siklus II terjadi peningkatanketuntasan yaitu 26 siswatuntas dengan persentase $87 \%$ sedangkan siswa yang tidak tuntas berjumlah 4 orang dengan persentase $13 \%$. Dengan demikian perbaikan pembelajaran dengan Model Student Teams Achievement Division (STAD) Berbantuan Media Gambar bisa ditarik kesimpulan berhasil karena hasil belajar meningkat mencapai tujaun yakni persentase $80 \%$.
\end{abstract}

Kata Kunci: Proses dan Hasil Belajar, Kreativitas, STAD, Media Gambar, IPA

\begin{abstract}
The research was conducted to improve the creativity and learning outcomes with the help of media images on the content of IPA in Theme 7 subtema 2 and 3. The research was conducted on May 7 to May 19, 2018 by the students of SD Negeri kecandran 01 Salatiga class 5 semester II academic year 2017 / 2018. The research used is classroom action research. Percentage of students' creativity measurement results experienced an increase from prasiklus with $40 \%$ percentage in cycle I increased to $80 \%$. After the action on the second cycle there is an increase in creativity to $90 \%$. The result of study in student prasiklus which is complete is 13 students with percentage $43 \%$, and not complete 17 students with percentage $57 \%$. After doing the action on the first cycle there is an increase in mastery of 18 students complete with $60 \%$ percentage and 12 students is not complete with the percentage of $40 \%$, the results of the improvement cycle I have not achieved the achievement indicator that is $80 \%$ mastery, then the
\end{abstract}


improvement of cycle II. After the implementation of cycle II, there was an increase of 26 students with $87 \%$ percentage while the unfinished students were 4 people with the percentage of $13 \%$. Thus the improvement of learning with the Model Student Teams Achievement Division (STAD) Assisted Media Image biased conclusions are drawn because the results of learning increased reach tujaun that percentage of $80 \%$.

Keywords: Learning Processes and Results, Creativity, STAD, Picture Media, Sains

\section{PENDAHULUAN}

Lembaga sekolah adalah dasar yang kuat untuk membangun sebuah bangsa, akan tetapi beberapa permasalahan yang sering terjadi di sekolah membuat terhambatnya usaha peningkatan kualitas pendidikan (Airlanda, 2016: 43). Karena itulah pendidikan merupakan suatu aspek kehidupan yang sangat penting dalam membangun sebuah bangsa menjadi bangsa yang maju. Pelaksanaan pendidikan terutama di sekolah, guru memiliki peran besar yaitu dengan saling berinteraksi dengan siswa dalam proses belajar mengajar. Perkembangan pendidikan di Indonesia sangat baik, salah satunya melalui pembelajaran tematik integratif untuk meningkatkan kualitas pendidikan. Pembelajaran tematik memiliki pengertian yaitu salah satu model pembelajaran terpadu yang menggunakan cara dan media tertentu untuk menghubungkan beberapa mata pelajaran sehingga dapat memberikan pengalaman bermakna untuk peserta didik, (Hermawati, 2018: 1). Muatan yang terdapat di dalam kurikulum 2013 salah satunya adalah Ilmu Pengetahuan Alam (IPA). Ilmu Pengetahuan Alam adalah mata pelajaran yang mempelajari peristiwa-peristiwa yang terjadi di Alam (Etimar 2017: 316). Menurut Widiantono dan Nyoto Harjono (2017: 200) bahwa proses pembelajaran IPA akan lebih baik dilakukan secara sistematis, hal tersebut untuk menumbuhkan kemampuan peserta didik dalam berpikir kritis, bekerja, dan bersikap secara ilmiah.

Semakin berkembangnya pendidikan terutama di Sekolah Dasar, seringkali mengalami berbagai macam kendala. Kendala yang sering kali dihadapi ialah masalah proses pembelajaran. Untuk menghadapi maslah itu dibutuhkan guru yang kreatif dalam merencanakan proses pembelajaran, dan mampu melakuakan proses pembelajaran secara aktif, inovatif, kreatif, serta menyenangkan. Guru dituntut tidak hanya memiliki pengetahuan yang luas namun juga harus memiliki keterampilan saat melakukan proses belajar di dalam kelas. Pemilihan model pembelajaran yang tepat akan mendukung terciptanya proses pembelajaran yang menumbuhkan semangat belajar siswa meningkat.

Seperti yang terjadi di kelas 5 SD Negeri Kecandran 01 yaitu kurangnya penggunaan media pembelajaran dan guru yang selalu berpatokan dengan buku guru yang disediakan oleh pemerintah. Akibatnya proses pembelajaran menjadi membosankan dan siswa cenderung kurang dapat menuangkan kreativitas mereka dalam proses pelaksanaan pembelajaran yang dilakukan di dalam kelas. Kurangnya siswa dalam menuangkan kreativitas berdampak besar pada menurunya motivasi siswa dalam melakukan pembelajaran sehingga hasil belajar siswa juga terpengaruh. Hasil belajar sebagian besar siswa yang diperoleh dari tes evaluasi kurang dari KKM. Dalam melakukan proses pembelajaran untuk menumbuhkan motivasi belajar siswa juga dibutuhkan model pembelajaran yang sesuai dengan materi yang akan disampaikan.

Model pembelajaran adalah suatu kerangka konseptual dalam rangka merancang dan melaksankan sebuah pembelajaran, mengorganisasikan pengalaman belajar guna mencapai tujuan atau kompetensi, dan sebagai patokan dalam proses pembelajaran dikarenakan berisi sintak pembelajatan yang sistematis. Model pembelajaran sangat berkaitan dengan media pembelajaran. Menurut Hamalik (2005: 15) pemakaian media pembelajaran dalam proses belajar mengajar dapat membangkitkan keinginan dan minat yang 
baru, membangkitkan motivasi dan rangsangan kegiatan belajar, dan bahkan membawa pengaruh - pengaruh psikologis terhadap siswa. Salah satunya dengan menerapkan model pembelajaran Student Teams Achievement Division atau sering disingkat STAD. Student Team Achievement Division (STAD) adalah untuk memotivasi siswa supaya dapat saling mendukung, membantu satu sama lain dalam menguasai kemampuan yang diajarkan oleh gurunya (Slavin, 2009: 12). Dalam menggunakan model pembelajaran diperlukan adanya bantuan media gambar.

Penggunaan media gambar dalam pembelajaran lebih mampu memudahkan siswa dalam memahami materi yang sedang dijelaskan oleh guru. Siswa tidak kesulitan dalam memahami materi pelajaran yang abstrak atau sulit untuk dibayangkan. Menurut Sadiman (2009:29), media gambar memiliki kelebihan diantaranya: (1) sifatnya komkret dan lebih realistis menunjukkan pokok masalah, (2) media gambar dapat mengatasi batas ruang dan waktu karena tidak semua benda dapat ditampilkan di kelas dan suatu peristiwa tidak dapat dilihat seperti adanya, dan (3) gambar dapat memperjelas suatu masalah.

Pembelajaran adalah salah satu kegiatan yang sangat tergantung pada proses belajar demi tercapainya suatu tujuan tertentu yaitu hasil belajar. Pembelajaran tematik integratif adalah pemblajaran yang diterapkan pada kurikulum 2013. Pembelajaran tematik integratif dijelaskan sebagai pembelajaran yang memadukan beberapa muatan pelajaran dalam satu kali tatap muka dan dikemas dalam sebuah tema sebagai pemersatu kegiatan pembelajaran (Mawardi 2014: 109). Maka, pembelajaran tematik disimpulkan pembelajaran terpadu yang menggunakan tema sebagai penghubung beberapa muatan pelajaran sehinggadapat memberikan pengalaman bermakna kepada pesertadidik.Dalam pembelajaran tematik terdapat beberapa muatan pelajaran di dalam setiap temanya yaitu Ilmu Pengetahuan Alam (IPA).

Tujuan pembelajaran IPA SD/MI: 1) Mendapat keyakinan terhadap kebesaran Tuhan Yang Maha Esa berdasarkan keberadapan, keindahan, dan keteraturan alam ciptaan-Nya, 2) Mengembangkan pengetahuan dan pemahaman konsep-konsep IPA ynag bermanfaat dan dapat diterapkan dalam kehidupan, 3) Mengembangkan rasa ingin tahu, sikap positif, dan kesadaran tentang adanya hubungan yang saling mempengaruhi antara IPA, lingkungan, teknolohi, dan masyarakat 4) Mengembangkan keterampilan proses untuk menyelidiki alam sekitar, memecahkan masalah, dan membuat keputusan, 5) Meningkatkan kesadarah untuk berperanserta dalam memelihara, menjaga, dan melestarikan lingkungan, 6) Meningkatkan kesadaran untuk menghargai alam dan segala keteraturannya sebagai salah satu ciptaan Tuhan, 6) Memperoleh bakal pengetahuan, konsep, dan keterampilan IPA sebagai dasar untuk melanjutkan pendidikan ke SMP/MTs (Tursinawati 2013: 69) .

Proses pembelajaran merupakan kegiatan interaksi antara guru dan siswa dimana akan diakhiri dengan proses evaluasi hasil belajar (Dimyati dan Mudjiono, 2006:3). pendapat yang lain mengemukakan pengertian dari proses pembelajaran yaitu sebagai proses terjadinya interasi antara pelajar, pengajar dalam upaya mencapai tujuan pembelajaran yang berlangsung dalam suatu lokasi tertentu dalam kurun satuan waktu tertentu pula (Hamalik 2006: 162). Jadi dapat disimpulkan bahwa proses pembelajaran merupakan suatu proses interaksi antara guru dan siswa yang diakhiri dengan proses evaluasi hasil belajar untuk mencapai tujuan pembelajaran dengan jangka waktu tertentu.

Hasil belajar adalah sesuatu yang diperoleh individu melalui proses belajar yang ditandai dengan adanya perubahan perilaku berupa pengetahuan dan kemampuan dalam berbagai hal. Menurut Abdurrahman (2009: 37) hasil belajar merupakan kemampuan yang diperoleh anak setelah melalui kegiatan belajar. Jadi dapat disimpulkan bahwa hasil belajar merupakan suatu ukuran ketercapaian tujuan belajar yang dijadikan sebagai tolak ukur kemampuan siswa setelah melalui kegiatan belajar (Vitasari 2013: 21). 
Model Pembelajaran Student Teams Achievement Division

Isjoni (2010: 74) menyatakan pembelajaran kooperatif tipe STAD adalah salah satu tipe kooperatif yang menekankan pembelajaran pada adanya aktivitas dan interaksi diantara siswa untuk saling memotivasi dan saling membantu dalam menguasai materi pelajaran guna mencapai prestasi yang maksimal. Student Team Achievement Division (STAD) adalah untuk memotivasi siswa supaya dapat saling mendukung, membantu satu sama lain dalam menguasai kemampuan yang diajarkan oleh gurunya (Slavin, 2009: 12). Kesimpulan yang diambil dari pendapat para ahli diatas, STAD adalah salah satu jenis model pembelajaran kooperatif yang menggunakan kerjasama kelompok dengan tujuan untuk memotivasi siswa agar dapat saling mendukung, membantu, bertukar ide dan gagasan dalam menguasai materi guna meningkatkan prestasi belajar.

Langkah-langkah pembelajaran model STAD menurut Slavin (2014: 147-154) adalah 1) Guru menyampaikan tujuan pembelajaran dan motivasi, 2) Guru membagi siswa dalam beberapa kelompok yang terdiri dari 4-5 siswa, 3) Guru menyampaikan materi dengan cara ceramah 4), Siswa melakukan kerja kelompok 5) Kuis/evaluasi, 6) Penghargaan presentasi tim.

\section{METODE PENELITIAN}

Jenis penelitian ini adalah Penelitian Tindakan Kelas, Penelitian Tindakan Kelas atau Classroom Action Research memiliki pengertian proses yang memberikan kepercayaan kepada pengembangan kekuatan berfikir reflektif, diskusi, penentuan keputusan dan kolektif dalam mengatasi kesulitan yang mereka hadapi dalam kegiatan (Sukmadinata, 2010:145).

Penelitian yang dilakukan menggunakan model pembelajaran Student Team Achievement Division (STAD) dengan berbantu media gambar di SD Negeri
Kecandran 01 semester 2 tahun pelajaran 2017/2018 pada bulan Mei 2018.Subjek penelitian yang digunakan adalah siswa kelas 5 SD Negeri Kecandran 01 semester 2 tahun pelajaran 2017/2018 dengan jumlah 30 siswa.

Teknik pengumpulan data yang digunakan berupa lembar aktivitas guru dan lembar aktivitas siswa, tes evaluasi, dan dokumentasi. Pengujian validitas dilakukan di sekolah yang sama pada tingkatan yang lebih tinggi. Jenis instrumen penelitian yang digunakan berupa tes evaluasi esai yang memiliki tingkat validitas $\leq 0,3$ dan dan ringkat reliabilitas soal pilihan ganda sebesar 0,885 pada soal siklus I dan 0,90 pada siklus II.

Teknik analisis data yang dipergunakan ialah analisis diskriptif kuantitatif. Data kuantitatif (angka) digunakan untuk menunjukan nilai kondisi awal, nilai setelah siklus I, nilai setelah siklus II, skor observasi guru dan siswa serta penilaian kreativitas siswa pada setiap siklusnya. Sedangkan untuk observasi guru dan siswa pengolahan data analisis menggunakan teknik analisis diskriptif komparatif sehingga dapat dibandingkan dengan nilai hasil belajar muatan IPA dan setelah dilakukan siklus I dan siklus II.

Indikator kinerja dari penelitian yang dilakukan pada siswa kelas 5 melalui model pembelajaran Student Team Achievement Division berbantu media gambar.

\section{HASIL DAN PEMBAHASAN}

Penelitian yang dilakukan sesuai langkah-langkah model pembelajaran Student Team Achievement Division berbantu media gambar dengan penelitian dilaksanakan dalam dua siklus, setiap siklus terdiri dari 3 pertemuan.

Hasil perbandingan penilaian kreativitas muatan IPA kelas 5 SD Negeri Kecandran 01 dari prasiklus, siklus I, dan siklus II mengalami peningkatan. Peningkatan yang terjadi dalam proses belajar dapat dilihat pada tabel 1 berikut. 
Tabel 1

Perbandingan Hasil Penilaian Kreativitas Muatan IPA Prasiklus, Siklus I, Dan Siklus II

\begin{tabular}{cccccccc}
\hline No & Kategori & Pra Siklus & Persen & Sikhus I & Persen & Siklus II & Persen \\
\hline 1 & Kreatif & 12 & $40 \%$ & 24 & $80 \%$ & 27 & $90 \%$ \\
\hline 2 & Tidak Kreatif & 18 & $60 \%$ & 6 & $20 \%$ & 3 & $10 \%$ \\
\hline & Jumlah & 30 & $100 \%$ & 30 & $100 \%$ & 30 & $100 \%$ \\
\hline
\end{tabular}

Berdasarkan tabel 1 dapat disimpulkan bahwa dengan menggunakan model pembelajaran Student Team Achievement Division berbantu media gambar dapat meningkatkan kreativitas siswa. Persentase hasil pengukuran kreativitas siswa mengalami mengalami peningkatan dari prasiklus dengan presentase $40 \%$ pada siklus
I mengalami peningkatan menjadi $80 \%$. Siklus ke II mengalami peningkatan kembali yaitu $90 \%$.

Peningkatan proses pembelajaran mempengaruhi hasil belajar siswa SD Negeri Kecandran 01 yang diperoleh siswa. Peningkatan hasil belajar siswa dapat dilihat pada tabel 2 berikut.

Tabel 2

Perbandingan Nilai Hasil Belajar Muatan IPA Prasiklus, Siklus I, Dan Siklus II

\begin{tabular}{|c|c|c|c|c|c|c|c|c|}
\hline \multirow{2}{*}{ No } & \multirow{2}{*}{$\begin{array}{c}\text { Ketuntasan } \\
\text { belajar }\end{array}$} & \multirow{2}{*}{ Nilai } & \multicolumn{2}{|c|}{ Prasiklus } & \multicolumn{2}{|c|}{ Siklus I } & \multicolumn{2}{|c|}{ Siklus II } \\
\hline & & & Jumlah & $\%$ & Jumlah & $\%$ & Jumlah & $\%$ \\
\hline 1 & Tuntas & $\geq 70$ & 13 & $43 \%$ & 18 & $60 \%$ & 26 & $87 \%$ \\
\hline 2 & $\begin{array}{l}\text { Belum } \\
\text { Tuntas }\end{array}$ & $<70$ & 17 & $57 \%$ & 12 & $40 \%$ & 4 & $13 \%$ \\
\hline \multicolumn{3}{|c|}{ Jumlah } & 30 & $100 \%$ & 30 & $100 \%$ & 30 & $100 \%$ \\
\hline \multicolumn{3}{|c|}{ Nilai Tertinggi } & \multicolumn{2}{|c|}{90} & \multicolumn{2}{|c|}{95} & \multicolumn{2}{|c|}{100} \\
\hline \multicolumn{3}{|c|}{ Nilai Terendah } & \multicolumn{2}{|c|}{30} & \multicolumn{2}{|c|}{30} & \multicolumn{2}{|c|}{50} \\
\hline \multicolumn{3}{|c|}{ Rata-rata } & \multicolumn{2}{|c|}{64.33} & \multicolumn{2}{|c|}{76,73} & \multicolumn{2}{|c|}{77,83} \\
\hline
\end{tabular}

Dari tabel 2 dapat di simpulkan bahwa setelah melakukan perbaikan pembelajaran dengan Model STAD berbantu media gambar hasil belajar siswa kelas 5 SD Negeri Kecandran 01 Salatiga mengalami peningkatan pada setiap siklus. Pada pra siklus siswa yang tuntas berjumlah 13 siswa dengan presentase $43 \%$, sedangkan siswayang tidak tuntas berjumlah 17 dengan presentase $57 \%$ dan nilai tertinggi pada pra siklus adalah 90 sedangakan nilai terendah 30. Setelah melakukan perbaikan pada siklus I terjadi peningkatan yaitu siswa yang tuntas berjumlah 18 orang dengan presentase $60 \%$ dan siswa yang tidak tuntas berjumlah 12 orang dengan presentase $40 \%$ dan nilai tertinggi pada siklus I yaitu 95 dan nilai terendah 30, hasil dari perbaikan siklus I belum mencapai indikator pencapaian yakni $60 \%$ ketuntasan, oleh sebab itu di laksanakan perbaikan siklus II. Setelah pelaksanaan siklus II terjadi peningkatan yaitu siswa yang tuntas berjumlah 26 dengan presentase $87 \%$ sedangakan siswa yang tidak tuntas berjumlah 4 orang dengan presentase $13 \%$ dan nilai tertinggi pada siklus II yaitu 100 dan nilai terendah 50. Dengan demikian perbaikan pembelajaran dengan Model Student Team Achievement Division Berbantu Media Gambar dapat di katakan berhasil karena hasil belar mencapai tujaun yakni presentase $80 \%$.

\section{Pembahasan}

Berdasarkan penelitian yang telah dulakukan di kelas 5 SD Negeri Kecandran 01 tema 7 sub tema 2 dan 3 mengalami penimgkatan proses dan hasil belajar dengan model pembelajaran Student Team Achievement Division berbantu media gambar mulai dari prasiklus sampai dengan siklus II. Persentase hasil pengukuran 
kreativitas siswa mengalami mengalami peningkatan dari prasiklus dengan presentase $40 \%$ pada siklus I mengalami peningkatan menjadi $80 \%$. Siklus ke II mengalami peningkatan kembali yaitu $90 \%$.

Meningkatnya kreativitas dalam proses pembelajaran juga mempengaruhi terhadap hasil belajar siswa kelas 5 SD Negeri Kecandran 01. Pada pra siklus siswa yang tuntas berjumlah 13 siswa dengan presentase $43 \%$, sedangkan siswayang tidak tuntas berjumlah 17 dengan presentase $57 \%$ dan nilai tertinggi pada pra siklus adalah 90 sedangakan nilai terendah 30. Setelah melakukan perbaikan pada siklus I terjadi peningkatan yaitu siswa yang tuntas berjumlah 18 orang dengan presentase $60 \%$ dan siswa yang tidak tuntas berjumlah 12 orang dengan presentase $40 \%$ dan nilai tertinggi pada siklus I yaitu 95 dan nilai terendah 30, hasil dari perbaikan siklus I belum mencapai indikator pencapaian yakni $60 \%$ ketuntasan, oleh sebab itu di laksanakan perbaikan siklus II. Setelah pelaksanaan siklus II terjadi peningkatan yaitu siswa yang tuntas berjumlah 26 dengan presentase $87 \%$ sedangakan siswa yang tidak tuntas berjumlah 4 orang dengan presentase $13 \%$ dan nilai tertinggi pada siklus II yaitu 100 dan nilai terendah 50. Dengan demikian perbaikan pembelajaran dengan Model Student Team Achievement Division Berbantu Media Gambar dapat di katakan berhasil karena hasil belar mencapai tujuan yakni presentase $80 \%$.

Berdasarkan penjelasan diatas, maka dengan menggunakan Student Team Achievement Division berbantu media gambar dalam pembelajaran muatan IPA SD Negeri Kecandran 01 kelas 5 tahun pelajaran 2017/2018 selaras dengan penelitian yang dilakukan oleh Bambang dengan judul Peningkatan Hasil Belajar Siswa Pada Mata Pelajaran IPS Melalui Penerapan Model Pembelajaran Kooperatif Tipe STAD di Kelas V SDN 1 Balukang, dari penelitian yang telah dilakukan presentase ketuntasan belajar kasikal pada siklus I hanya mencapai $73,07 \%$. Pada siklus II ketuntasan belajar klasikal mecapai 92,30\%. Penelitian lain yang dapat mendukung yaitu Santi Utami diketahui rerata nilai hasil belajar siswa mengalami peningkatan setelah dilaksanakan metode Student Team Achievement Division, pada siklus pertama rerata nilai kelas 7.06 dan pada siklus kedua terjadi penurunan nilai siswa dengan re- rata nilai 5.9 dan dilanjutkan pada siklus ketiga sehingga diperoleh rerata nilai menjadi 7.09.

\section{PENUTUP}

Berdasarkan penelitian dan pembahsan yang telah dijelaskan dapat ditarik kesimpulan bahwa penggunaan model Student Team Achievement Division berbantu media gambar terbukti berhasil meningkatkan proses dan hasil belajar siswa kelas 5 SD Negeri Kecandran 01 tema 7 sub tema 2 dan 3. Hal tersebut dapat terlihat dari peningkatan hasil penilaian kreativitas siswa pada muatan IPA. Persentase hasil pengukuran kreativitas siswa mengalami mengalami peningkatan dari prasiklus dengan presentase $40 \%$ pada siklus I mengalami peningkatan menjadi $80 \%$. Siklus ke II mengalami peningkatan kembali yaitu $90 \%$.

Bersamaan dengan meningkatnya proses pembelajaran, berpengaruh juga terhadap hasil belajar siswa kelas $5 \mathrm{SD}$ Negeri Kecandran 01. Peningkatan ini ditunjukan dengan perbandingan hasil belajar muatan IPA berdasarkan ketuntasan belajar dengan $\mathrm{KKM} \geq 70$. Pada prasiklus siswa yang tuntas berjumlah 13 siswa dengan presentase $43 \%$, sedangkan siswayang tidak tuntas berjumlah 17 dengan presentase $57 \%$ dan nilai tertinggi pada pra siklus adalah 90 sedangakan nilai terendah 30. Setelah melakukan perbaikan pada siklus I terjadi peningkatan yaitu siswa yang tuntas berjumlah 18 orang dengan presentase $60 \%$ dan siswa yang tidak tuntas berjumlah 12 orang dengan presentase $40 \%$ dan nilai tertinggi pada siklus I yaitu 95 dan nilai terendah 30, hasil dari perbaikan siklus I belum mencapai indikator pencapaian yakni $60 \%$ ketuntasan, oleh sebab itu di laksanakan perbaikan siklus II. Setelah pelaksanaan siklus II terjadi peningkatan yaitu siswa yang tuntas berjumlah 26 dengan presentase $87 \%$ sedangakan siswa yang tidak tuntas berjumlah 4 orang dengan presentase $13 \%$ dan nilai tertinggi pada siklus II yaitu 
100 dan nilai terendah 50. Dengan demikian perbaikan pembelajaran dengan Model Student Team Achievement Division Berbantu Media Gambar dapat meningkatkan proses dan hasil belajar siswa kelas 5 SD Negeri Kecandran 01 pada tahun ajaran 2017/2018.

\section{DAFTAR PUSTAKA}

Abdurrahman, M. 2009. Pendidikan Bagi Anak Berkesulitan Belajar. Jakarta: PT Rineka Cipta.

Airlanda, G. S. 2016. Analisis Kualitas Pendidikan Ditinjau dari Penerapan Kebijakan Sekolah Gratis di SMA Negeri 1 Weru Kabupaten Sukoharjo. Jurnal Pendidikan Sains. 4(1): 43.

Dimyati. dan Mudjiono. 2006. Belajar dan Pembelajaran. Jakarta: PT Rineke Cipta.

Etimar. 2017. Pengaruh Variasi Media Video Terhadap Minat Belajar Siswa Kelas IV SD Negeri Golo Yogyakarta. Jurnal Pendidikan Guru Sekolah Dasar. 4(6): 316.

Hamalik, Oemar. 2005. Strategi Belajar Mengajar. Bandung: Mandar Maju.

Hamalik, Oemar. 2006. Proses Belajar Mengajar. Bandung: Bumi Aksara.

Hermawati, Z., dan Kristin, F., Anugraheni, I. 2018. Peningkatan Hasil Belajar Dan Keaktivan Pada Mata Pelajaran Matematika Melalui Model Pembelajaran Learning Together Siswa Sekolah Dasar. Jurnal Pendidikan Dasar. 6(1): 36

Isjoni. (2010). Pembelajaran Kooperatif Meningkatkan Kecerdasan
Komunikasi Antar Peserta Didik. Yogyakarta: Pustaka Pelajar.

Mawardi, M. 2014. Pemberlakuan Kurikulum SD/MI Tahun 2013 dan Implikasinya Terhadap Upaya Memperbaiki Proses Pembelajaran Melalui PTK. Scholaria: Jurnal Pendidikan dan Kebudayaan, 4(3): 109.

Sadiman, A.S. 2009. Media Pendidikan, Pengertian, Pengembangan dan Pemanfaatannya. Jakarta: Rajawali Pers.

Slavin, Robert. 2009. Cooperative Learning Teori, Riset dan Praktik. Bandung: Nusa Media

Slavin, R. E. 2014. Cooperative Learning. Bandung: Nusa Media.

Sukmadinata, N. S. 2010. Metode Penelitian Pendidikan. PT Remaja Rodakarya.

Tursinawati. 2013. Analisis Kemunculan Sikap Ilmiah Siswa dalam Pelaksanaan Percobaan pada Pembelajaran IPA di SDN Kota Banda Aceh. Jurnal Pionir.1(1): 69.

Vitasari, R., dan Joharman, Suryandari, K. C. 2011. Peningkatan Keaktifan Dan Hasil Belajar Matematika Melalui Model Problem Based Learning Siswa Kelas V SD Negeri 5 Kutosari. Jurnal Pendidikan Kimia. 4(3): 3

Widiantono, N., dan Harjono, N. 2017. Penerapan Model Pembelajaran Interaktif untuk Meningkatkan Aktivitas dan Hasil Belajar IPA Siswa Kelas 5 SD. Scholaria. 7(3): 200. 